\title{
DESAIN SISTEM PENGONTROLAN PINTU AIR OTOMATIS BERDASARKAN LEVEL KETINGGIAN AIR PADA KALI REMU SORONG PAPUA BARAT
}

\author{
Markus Dwiyanto Tobi, ST., MT \\ Jurusan Teknik Elektro \\ Politeknik Katolik Saint Paul Sorong \\ Email : dwiyanto@poltekstpaul.ac.id
}

\begin{abstract}
ABSTRAK
Kota Sorong sebagai salah satu kota berkembang di Provinsi Papua Barat hampir selalu mengalami kebanjiran di saat musim hujan yang disebabkan oleh luapan air kali remu. Pertumbuhan pemukiman di sekitar area kali merupakan salah satu penyebab mengecilnya luasan lebar kali. Selain itu kurang efisien dan tidak otomatisnya buka tutup pintu air kali remu yang berguna untuk membuang kelebihan volume air ke laut juga merupakan salah satu faktor penyebab kebanjiran. Pengawasan terhadap ketinggian air pada kali remu merupakan pekerjaan yang tidak terlalu berat, namun jika terus menerus hanya digunakan satu sistem yakni manual maka sering terjadi kelalaian dalam pengawasannya. Selain itu masyarakat sekita area kali dan petugas pengawas seharusnya menerima informasi tentang level ketinggian air dan status level secara cepat dan akurat untuk mengantisipasi hal buruk yang akan terjadi. Desain sistem prototipe alat pengendali pintu air otomatis ini menggunakan sistem pengiriman informasi melalui sms berbasis mikrokontroler dan menggunakan media interface GSM Shield antara pengiriman SMS dengan pintu air otomatis. Untuk menerjemahkan perintah yang diterima melalui SMS dan perintah untuk memberikan informasi adalah sensor PING. Selain itu, mikrokontroler berperan sebagai otak yang memberikan perintah untuk menggerakan Motor DC dalam hal membuka dan menutup pintu air kali remu secara otomatis.
\end{abstract}

Kata kunci : Mikrokontroler, GSM Shield, Sensor PING Dan Motor DC

\section{PENDAHULUAN}

\section{Latar belakang}

Kota Sorong sebagai salah satu Kota di wilayah Provinsi Papua Barat merupakan Kota yang memiliki kemajuan pembangunan sangat pesat. Perkembangan kemajuan Kota Sorong tentunya membawa dampak yang cukup siginifikan terhadap perkembangan perekonomian penduduk Kota Sorong.

Pertumbuhan perekonomian tersebut seiring dengan bertambahnya jumlah penduduk yang dating dan menetap di Kota Sorong. Pertambahan jumlah penduduk ini mengakibatkan semakin banyaknya perumahan yang dibangun di area sekitar Kali Remu, dimana Kali Remu merupakan kali terbesar yang ada di Kota Sorong.

Pada saat musim hujan, kali Remu ini sering meluapkan air yang dapat menyebabkan terjadinya kebanjiran di Kota Sorong. Banjir luapan air Kali Remu ini bukan hanya disebabkan karena banyaknya pemukiman sekitar area Kali yang menyebabkan menyempitnya luasan kali, namun disebabkan juga karena tidak efektifnya sistem pembuangan volume air Kali Remu ke pembuangan di Laut. Kurang efektifnya sistem pembuangan luapan air Kali Remu ke laut disebabkan cara pembuangan masih dilakukan secara manual oleh petugas. 
Cara manual ini mempunyai faktor kekurangan yaitu, apabila para penjaga pintu tersebut lalai dalam tugasnya, maka tuas pembuka dan penutup pintu tidak diberfungsikan dengan baik sehingga dapat menyebabkan air meluap ke lingkungan warga disekitar Kali Remu

Agar proses pengawasan lebih baik dan juga lebih efektif, peneliti merancang sebuah desain sistem pengawasan yang bersifat otomatis dalam hal buka tutup pintu air kali remu dan juga dilengkapi dengan warning sistem berbasis SMS untuk mengirim pesan broadcast kepada warga sekitar Kali Remu dan petugas pengawas pintu air tentang level ketinggian air dan status level air Kali Remu

\section{Perumusan Masalah}

Berdasarkan latar belakang di atas, maka rumusan masalah dalam penelitian ini adalah bagaimana mendesain sebuah sistem otomatis membuka dan menutup pintu air secara efisien dan akan memberikan informasi ketinggian level air dan status level melalui pemberitahuan pesan singkat (SMS).

\section{Batasan Masalah}

Dalam perancangan pembuatan sistem ini terdapat beberapa pembatasan masalah, yaitu :

1) Informasi tentang ketinggian air menggunakan Sensor PING.

2) Buka tutu pintu otomatis menggunakan motor dc.

\section{Tujuan}

Tujuan penelitian ini adalah merancang bangun sistem pengontrolan pintu air otomatis menggunakan sistem pengiriman informasi melalui SMS.

\section{LANDASAN TEORI}

\section{Deskripsi pin SIM900 GSM/GPRS}

IcomSat digunakan untuk pengiriman data yang menggunakan sistem GPRS. IcomSat dikontrol dengan menggunakan AT-Commands.
SIM900 GSM/GPRS dikontrol melalui perintah AT (GSM 07.07, 07.05, dan SIMCOM).

Berikut ini adalah deskripsi pin SIM900 GSM/GPRS seperti gambar dibawah ini.

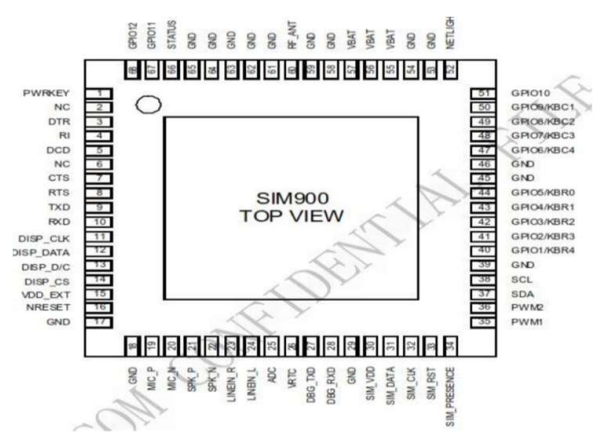

Gambar 1. Deskripsi pin SIM900 GSM/GPRS

\section{Mikrokontroler Atmega328}

AVR adalah sebuah mikrokontroler yang dibuat dengan menggunakan arsitektur Harvard dimana data dan program disimpan secara terpisah sehingga sangat baik untuk sebuah sistem karena terlindungi dari interferensi yang dapat merusak isi program. Salah satu mikrokontroler keluarga AVR yang dipergunakan yaitu ATmega328.

ATMega328 adalah mikrokontroller keluaran dari atmel yang mempunyai arsitektur RISC (Reduce Instruction Set Computer) yang dimana setiap proses eksekusi data lebih cepat dari pada arsitektur CISC (Completed Instruction Set Computer).

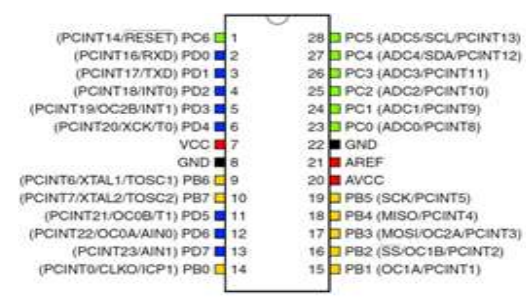

(Sumber: http://www.arduino.cc/02/11/2016)

Gambar 2. Konfigurasi Pin ATMega328 pada board arduino 


\section{METODOLOGI KEGIATAN DAN PERANCANGAN SISTIM}

\section{Perancangan Model Sistim}

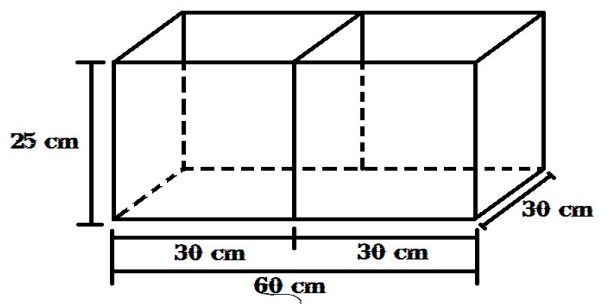

Gambar 3. Rangka Box

Dalam melakukan Perancangan Dan Pembuatan pintu otomatis kali remu dan infomasi ketinggian air. Terlebih dahulu kita membuat rangka box, dimana rangka box ini di perlukan untuk dudukan atau letak Motor Servo, HC-SR04 dan Buzzer, setelah pembuatan rangka sudah jadi. yang kedua kita harus mengukur untuk besaran dari mika yang kita perlukan, rangka box ini terbuat dari kaca mika. Dalam pembuatan rangka ini kita harus benar-benar sudah menghitung untuk mempastikan bahanbahan yang akan dipasangkan pas dan tidak kurang

\section{Perancangan Perangkat Keras (hardware)}

Perancangan bangun sistem pengontrolan pintu air otomatis menggunakan sistem informasi melalui sms digambarkan dalam bentuk diagram blok perancangan rangkaian antar muka sebagai berikut :

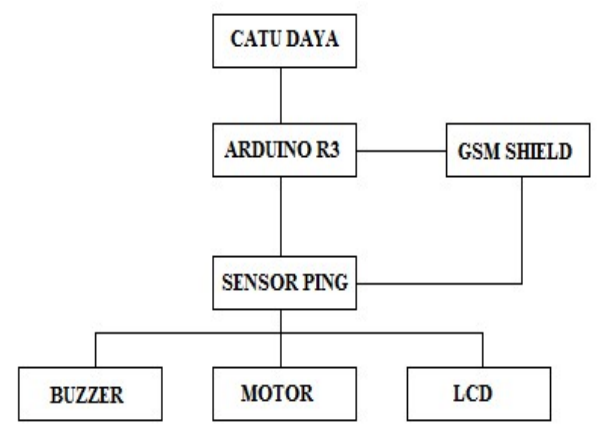

Gambar 4. Blog Diagram Sistem

Dari gambar diagram blok sistem diatas cara kerja dari diagram blok perancangan rangkaian antar muka adalah sebagai berikut :
Pertama-pertama tegangan 12 volt masuk melalui Arduino UNO dan tegangan 5 volt masuk melalui GSM Shield barulah setelah itu akan masuk ke rangkaian yang berfungsi sebagai perintah untuk menjalankan sensor ping, motor DC, LCD dan Buzzer. Dari sensor akan mendeteksi ketinggian air, maka servo akan bekerja jika nilai baca sensor $<15$ pintu akan terbuka dan nilai baca sensor $>15$ maka pintu akan tertutup, jika nilai baca sensor $<7$ maka buzzer akan berbunyi sebagai tanda bahwa pintu kali remu bermasalah.

\section{Perancangan Perangkat Lunak (Algoritma)}

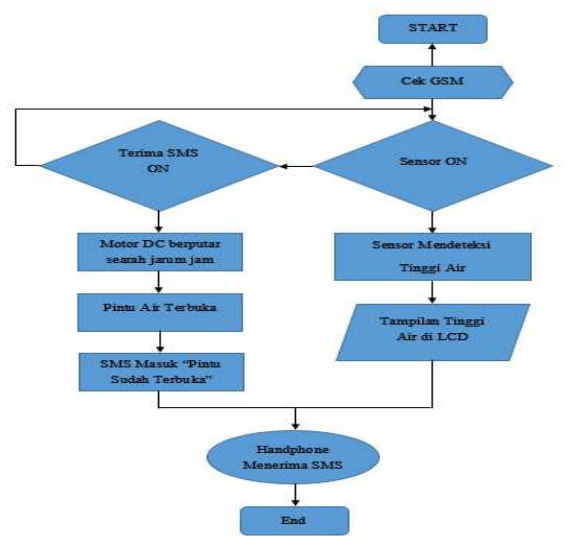

Gambar 5. flowchart

Sistem kerja perangkat lunak ini adalah, jika nilai baca sensor PING kurang dari $15(<15)$ program yang akan di jalankan adalah motor servo, dan GMS Shield, dan akan berlanjut adalah, jika PING atau sensor jarak membaca lebih dari 15 (>15) pintu kali remu akan tertutup dan $<15$ pintu kali remu akan terbuka dan apa bila servo tidak bekerja maka buzzer akan berbunyi dan tampilan pintu bermasalah akan ditampilkan di LCD.

\section{Perancangan Pengujian Sistem}

Dari hasil perancangan perangkat keras dan perangkat lunak, kemudian akan dilakukan pengujian disetiap sistem pada perangkatperangkat tersebut. Pengujian sistem tersebut meliputi :

a. GSM Shield.

b. Arduino Uno Rev.1.3. 
c. HC-SR04

d. Port I/O Arduino Uno Rev.1.3.

e. Motor Servo

f. Buzzer

g. LCD $16 \times 4$

\section{PENGUJIAN ALAT DAN PEMBAHASAN}

\section{Pengujian catu daya}

Dari hasil pengukuran terdapat adanya persentase kesalahan pada titik pengukuran Output Rangkaian Catu Daya sebesar ( 6,5\%). input tegangan pada rangkaian driver sebesar 12 volt dan telah diuji pada rangkaian catu daya dengan mengeluarkan tegangan 11,22 volt, yang mampu mengaktifkan rangkaian driver.

Agar alat yang dibuat dapat bekerja sesuai dengan fungsinya, maka diperlukan sumber tegangan listrik sebagai catu daya. Alat ini menggunakan catu daya yang merubah tegangan bolak-balik $(A C)$ menjadi tegangan searah $(D C)$. Rangkaian catu daya yang digunakan mendapatkan sumber tegangan dari PLN sebesar 220V AC. Tegangan tersebut kemudian diturunkan menjadi $7,5 \mathrm{~V}$ ACmelalui trafo penurun tegangan (Step Down).

\begin{tabular}{|c|c|c|c|c|c|}
\hline No & Titik pengukuran & $\begin{array}{c}\text { Hasil pengukuran } \\
\text { (V) }\end{array}$ & $\begin{array}{c}\text { Seharusnya } \\
\text { (V) }\end{array}$ & $\begin{array}{c}\% \\
\text { Error }\end{array}$ & Ket \\
\hline l & Output Rangkaian Catu & 12,14 & 12 & 0,11 & Baik \\
& Daya & & & & \\
& & & & & \\
\hline
\end{tabular}

Hasil perhitungan presentase kesalahan ( $\%$ Error)

Error $=\frac{\text { Seharusnya }(\mathrm{V})-\text { Hasil Pengukuran }(\mathrm{V})}{\text { Seharusnya }(\mathrm{V})} \times 100 \%$.

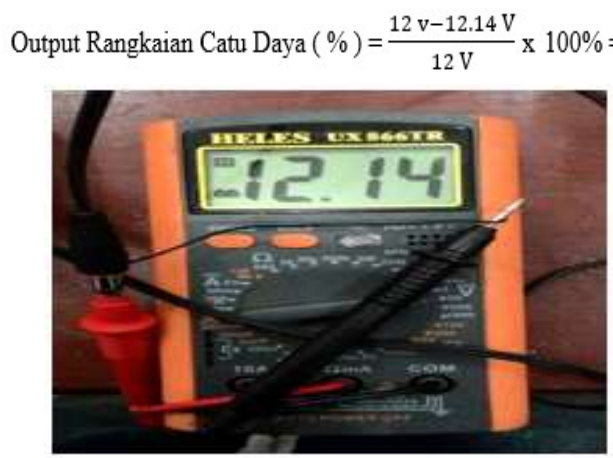

Gambar 6. Pengukuran catu daya

\section{Pengujian pada pintu tertutup}

\begin{tabular}{|c|c|c|c|c|}
\hline No & Pengujian & Hasil pengukuran & Hasil sebenarnya & \% Error \\
\hline 1 & Motor servo & 0.58 volt & 12 volt & $95.1 \%$ \\
\hline
\end{tabular}

Presentase Kesalahan (\% Error)

$$
\begin{aligned}
& \left|\frac{\text { Hasil Sebenarnya }- \text { Hasil Pengukuran }}{\text { Hasil Sebenarnya }}\right| \times 100 \% \ldots \ldots \ldots(i) \\
& \mid \frac{12-0.58}{12} \times 100 \%=95.1 \%
\end{aligned}
$$

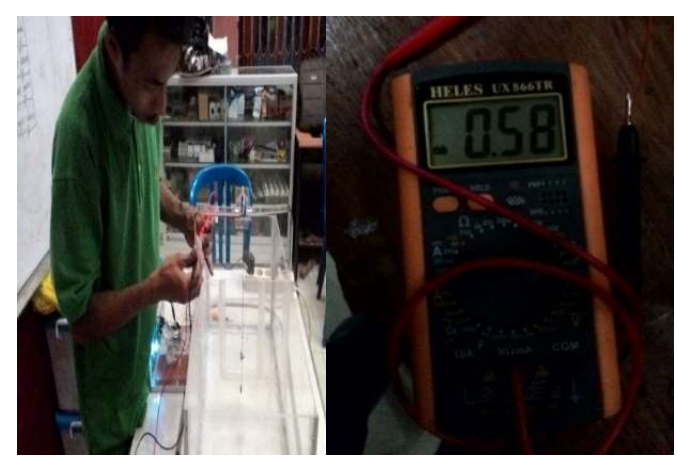

Gambar 7. Pengukuran pintu tertutup

\section{Pengujian pada pintu terbuka}

\begin{tabular}{|c|c|c|c|c|}
\hline No & Pengujian & Hasil pengukuran & Hasil sebenarnya & \% Error \\
\hline 1 & Motor servo & 0.12 volt & 12 volt & $99 \%$ \\
\hline
\end{tabular}

Presentase Kesalahan (\% Error)

$\left|\frac{\text { Hasil Sebenarnya }- \text { Hasil Pengukuran }}{\text { Hasil Sebenarnya }}\right| \times 100 \% \ldots \ldots . . .(i)$

$\left|\frac{12-0.12}{12}\right| \times 100 \%=99 \%$

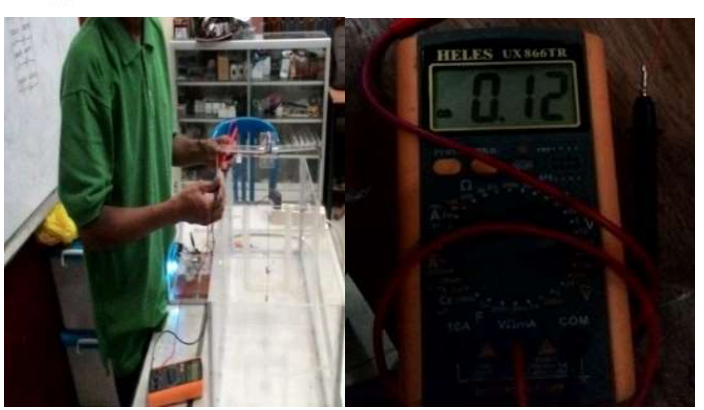

Gambar 8. Pengukuran pada pintu terbuka

\section{Pengujian buzzer}




\begin{tabular}{|c|c|c|c|c|}
\hline No & Pengujian & Hasil pengukuran & Hasil sebenarnya & \% Error \\
\hline 1 & Buzzer & 0.16 volt & 5 volt & $96.8 \%$ \\
\hline
\end{tabular}

Presentase Kesalahan (\% Error)

$\left|\frac{\text { Hasil Sebenarnya }- \text { Hasil Pengukuran }}{\text { Hasil Sebenarnya }}\right| \times 100 \% \ldots \ldots . . .(i)$

$\left|\frac{5-0.16}{5}\right| \times 100 \%=96.8 \%$

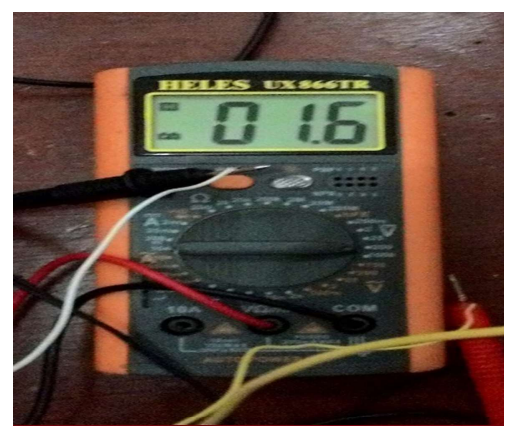

Gambar 9. Pengukuran buzzer

\section{Pengujian LCD}

Pengujian LCD 16x2 dilakukan dengan tujuan untuk mendapatkan parameter berupa tampilan karakter pada LCD sesuai dengan keinginan. Pengujian dilakukan dengan memprogram karakter atau tulisan yang ingin ditampilkan pada LCD

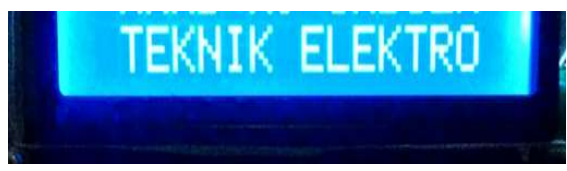

Gambar 10. Pengujian led 16x2

Listing program dimulai dengan proses inisialisasi LCD diantaranya konfigurasi mode (8 bit), baris, font, proses mematikan display, clear display, posisi kursor, pergeseran display (off), proses menghidupkan dispay, dan karakter tidak berkedip. Kemudian dilanjutkan dengan proses inisialisasi pengiriman data

\section{Pengujian program}

Program ini akan berkomunikasi dari komputer ke pengontrolan pintu otomatis dengan berbagai jenis tampilan program yang dapat di transfer ke pengontrolan pintu otomatis.
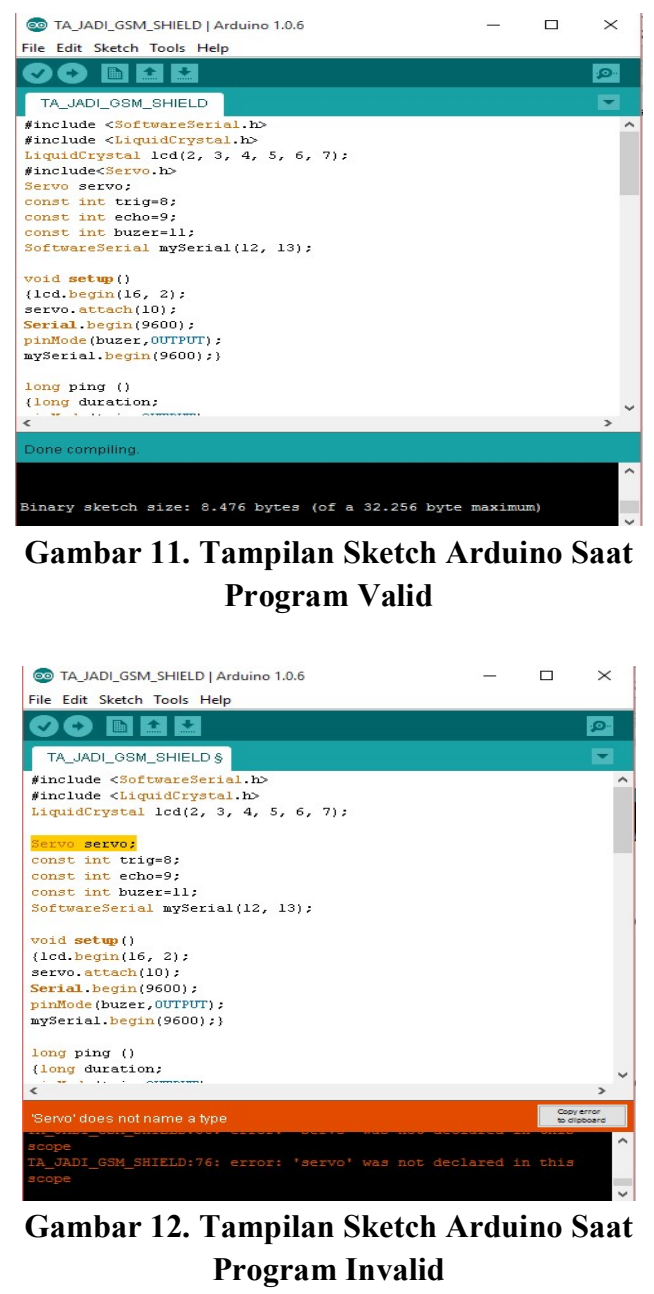

Penjelasan dari gambar di atas adalah, apabila program di masukan dan tidak terjadi masalah atau bisa dikatakan program itu True atau (benar) atau program itu valid, dari aplikasi arduino 1.0.6 akan memberikan comentar Done compiling atau (dilakukan compilasi), tetapi apabila program itu wrong atau (salah) atau program invalid aplikasi arduino 1.0.6 akan memberikan expected atau (diharpkan) untuk menambah atau mengurangi tanda atau bahasa program yang dipakai 


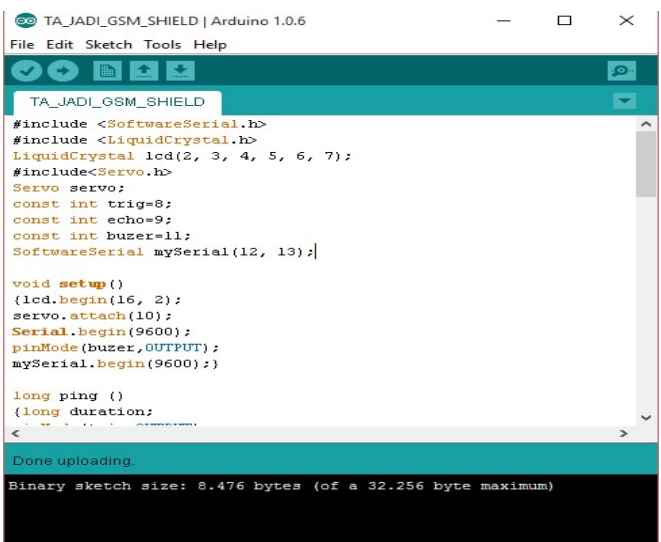

Gambar 13. Tampilan Sketch Arduino Saat Program telah berhasil di upload

Ini adalah tampilan sketch apabila program yang di upload masuk ke dalam aplikasi arduino ini berhasil.

\section{Pengujian PING}
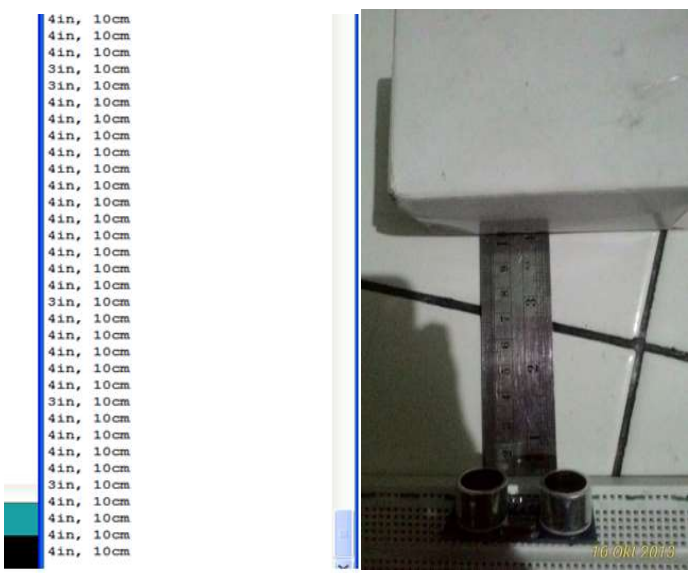

Gambar 14. Pengujian PING

\begin{tabular}{|c|c|c|c|}
\hline No & Hasil Pengukuran serial monitor & Hasil Sebenarnya & $\%$ Error \\
\hline 1 & $10 \mathrm{~cm}$ & $10 \mathrm{~cm}$ & $0 \%$ \\
\hline
\end{tabular}

Presentase Kesalahan (\% Error)

$\left|\frac{\text { Hasil Seharusnya }- \text { Hasil Pengukuran serial monitor }}{\text { Hasil Sebenarnya }}\right|$ $\times 100 \% \ldots \ldots(v i i)$

$$
\left|\frac{10-10}{10}\right| \times 100 \%=0 \%
$$

\section{Pengujian port I/O}

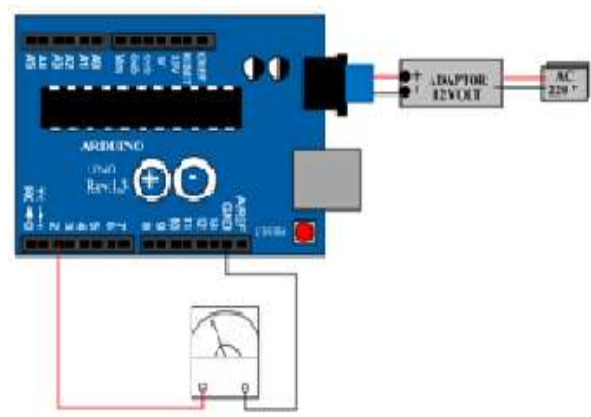

Gambar 15. Pengujian port I/O

Pengujian Port I/O arduino uno Rev.1.3 dapat dilakukan dengan cara mengukur tegangan keluaran pada portnya. Untuk melakukan pengujian pada Port I/O arduino uno Rev.1.3 dilakukan langkah-langkah sebagai berikut :

1. Menyambungkan arduino uno Rev.1.3 ke komputer dengan menggunakan Jalur komunikasi USB serial untuk arduino uno Rev.1.3.

2. Memberikan tegangan 7-12 VDC untuk mengaktifkan arduino uno Rev.1.3 atau bisa langsung menghidupkan arduino uno Rev.1.3 dengan cara menyambungkan Jalur komunikasi USB serial untuk arduino uno Rev.1.3.

3. Setelah arduino uno Rev.1.3 aktif, transfer program yang telah di buat di software arduino, dengan cara klik tanda panah yang ada di kanan atas pada software arduino atau bisa langsung menekan Ctrl-U.

4. Mengukur semua keluaran portnya mulai dari port 0 sampai dengan port 13 dengan menggunakan Avometer. Jika semua port mengeluarkan tegangan sebesar 5 VDC maka Arduino Uno Rev 1.3 itu dalam kondisi baik.

Adapun tabel hasil pengukuran yang telah diuji pada pengujian Port $\mathrm{I} / \mathrm{O}$ arduino uno rev, 1.3 adalah sebagai berikut :

\begin{tabular}{|c|l|c|c|c|}
\hline No & Titik Pengujian & Hasil Pengukuran & Hasil Sebenarnya & $\%$ Error \\
\hline 1 & Port 1 & 4,96 VDC & 5 VDC & $8 \%$ \\
\hline
\end{tabular}


Presentase Kesalahan (\% Error)

$\left|\frac{\text { Hasil Seharusnya }- \text { Hasil Pengukuran }}{\text { Hasil Sebenarnya }}\right| \times 100 \% \ldots . . . .$. (vii)

$\left|\frac{5-4,96}{5}\right| \times 100 \%=8 \%$

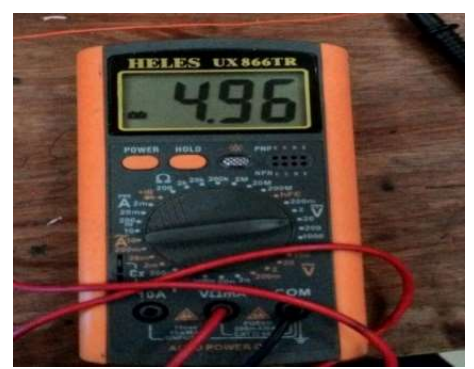

Gambar 16. Pengukuran port I/O

\section{Pengujian Pengiriman Data}

Motor servo telah memberikan sinyal modulasi lebar pulsa melalui kabel kontrol. Menentukan posisi sudut putaran dari poros motor servo sudut dari motor servo akan berputar ke posisi sudut $180^{\circ}$ dan kembali berputar ke arah posisi $0^{\circ}$. Kemudian jika motor servo tidak bekerja maka buzzer akan berbunyi dan GSM akan memberikan informasi melewati sms jika ada kesalahan dengan pintu kali remu seperti gambar dibawah ini.
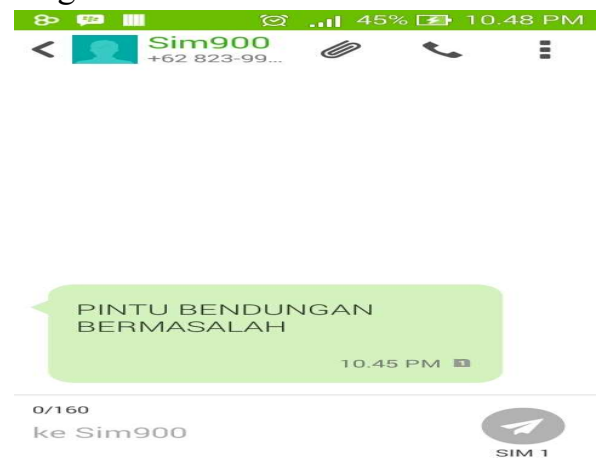

Gambar 17. Sms pintu kali remu bermasalah

\section{Listning program pintu air otomatis}

/*program pengontrolan pintu air otomatis menggunakan sistem pengiriman informasi melaui SMS*/ \#include $<$ SoftwareSerial.h $>$ \#include $<$ LiquidCrystal.h $>$

LiquidCrystal lcd(12, 13, 3, 5, 6, 7);

\#include $<$ Servo.h $>$

Servo servo;

const int trigPin $=2$;

const int echoPin $=4$;

const int buzer $=11$;

SoftwareSerial mySerial $(9,10)$;

void setup()

$\{$ lcd.begin $(16,2)$;

servo.attach(8);

Serial.begin $(9600)$;

pinMode(buzer,OUTPUT);

mySerial.begin(9600);

delay(100);

SendSMSAwal();

delay(1000);

void loop()

\{long duration, inches, $\mathrm{cm}$;

pinMode(trigPin, OUTPUT);

digitalWrite(trigPin, LOW);

delayMicroseconds(2);

digitalWrite(trigPin, HIGH);

delayMicroseconds(10);

digitalWrite(trigPin, LOW);

pinMode(echoPin, INPUT);

duration = pulseIn (echoPin, HIGH);

inches $=$

microsecondsToInches(duration);

$\mathrm{cm}=$

microsecondsToCentimeters(duration);

lcd.clear();

lcd.print(millis ()$/ 1000)$;

lcd.setCursor $(0,0)$;

lcd.print("TINGGI AIR =");

lcd.setCursor $(12,0)$;

lcd.print $(\mathrm{cm})$;

lcd.print("cm");

delay(250);

if (mySerial.available ()$>0$ )

$\{$ Serial.write(mySerial.read());

if $(\mathrm{cm}<=15 \& \& \mathrm{~cm}>=7)$ 
\{mySerial.println("Kali remu Penuh");

mySerial.print $(\mathrm{cm})$;

mySerial.print(" $\mathrm{cm} ")$;

SendSMSKali remu();

servo.write(0);

lcd.setCursor $(3,1)$;

lcd.print("BUKA PINTU");

$\operatorname{delay}(1000) ;\}$

if $(\mathrm{cm}<=7)$

\{mySerial.println("PINTU MACET");

mySerial.print $(\mathrm{cm})$;

mySerial.print(" $\mathrm{cm} ")$;

SendSMSMacet();

digitalWrite(buzer,HIGH);

lcd.setCursor $(0,1)$;

lcd.print("PINTU BERMASALAH");

delay(1000);

else //pake ini untuk matikan buzzer

digitalWrite(buzer,LOW);

if $(\mathrm{cm}>=15)$

\{mySerial.println("TUTUP PINTU");

mySerial.print $(\mathrm{cm})$;

mySerial.print(" cm");

SendSMSTutup();

servo.write(180);

lcd.setCursor $(3,1)$;

lcd.print("TUTUP PINTU");

delay(1000); $\}$

\}

long microsecondsToInches(long

microseconds)

\{return microseconds / 74 / 2; $\}$

long microsecondsToCentimeters(long microseconds)

\{return microseconds / 29 / 2;

void SendSMSAwal()

\{mySerial.println("AT+CMGF=1");

delay(1000);

mySerial.println("AT+CMGS=|"+628124

8852180`"\r");

delay(1000);
mySerial.println("APLIKASI READY");

delay(100);

mySerial.println((char)26);

delay (5000);

void SendSMSKali remu()

\{mySerial.println("AT+CMGS=|"+62812

48852180〉"\r");

delay(1000);

mySerial.println("KALI REMU

PENUH");

delay (100);

mySerial.println((char)26);

delay(1000); $\}$

void SendSMSMacet()

$\{$ mySerial.println("AT+CMGS $=\mid "+62812$

48852180 '"r");

delay(1000);

mySerial.println("WARNING PINTU

MACET");

delay (100);

mySerial.println((char)26);

delay(1000);

void SendSMSTutup()

\{mySerial.println("AT+CMGS=|"+62812

48852180\"\r"); // Replace x with mobile number

delay(1000);

mySerial.println("PINTU AIR TUTUP");

delay(100);

mySerial.println((char)26);

delay(1000);

\section{Kesimpulan}

\section{PENUTUP}

1. Status buka tutup pintu air Kali Remu dinformasikan melalui pesan singkat menggunakan jalur komunikasi.

2. Pengontrolan pintu air otomatis dapat dikendalikan dengan motor servo untuk membuka dan menutup pintu kali remu. 
3. Sensor untuk mendeteksi ketinggian air yang dapat memerintahkan motor servo, sehingga motor servo bekerja secara otomatis

\section{Saran}

1. Informasi ketinggian air dapat diintegrasikan dengan aplikasi API yang dapat bekerja di jaringan internet.

2. Hasil pembacaan sensor ketinggian air dapat diintegrasikan dengan sistem log monitoring sehingga data ketinggian air dapat disimpan dan menjadi bahan pertimbangan dalam mengambil keputusan.

3. Perlu pengembangan lebih lanjut tentang factor keamanan dan respon sistem dalam pengontrolan pintu air otomatis.

\section{DAFTAR PUSTAKA}

\section{Internet :}

Fatehnia, M., S. Paran, S. Kish, and K. Tawfiq. "Automating double ring infiltrometer with an Arduino microcontroller." Geoderma 262 (2016): 133-139.

Markus Dwiyanto Tobi. (2015). RANCANG BANGUN ROBOT BERODA PEMADAM API MENGGUNAKAN ARDUINO UNO REV.1.3. Electro luceat, 1(1), 4-12. http://doi.org/10.5281/zenodo.1344099

Pudasaini, Sanam, Anuj Pathak, Sukirti Dhakal, and Milan Paudel. "Automatic Water Level Controller with Short Messaging Service (SMS) Notification." International Journal of Scientific and Research Publications 4, no. 9 (2014): 1-4.

Tobi, Markus Dwiyanto. "Rancang Bangun Robot Beroda Pemadam Api Menggunakan Arduino Uno Rev. 1.3." Electro Luceat 1, no. 1 (2015).
Anonim ${ }^{1}$.

http://elib.unikom.ac.id/files/disk1/632/jbpt

unikompp-gdl-depemagini 31577-11-

unikom_d-l.pdf diakses tanggal 7 juni 2018.

Anonim $^{2}$

https://www.arduino.cc/en/Main/Ardui

noGSMShield diakses tanggal 7 juni

2018.

Anonim $^{3}$. http: $/ / w w w$.arduino.cc diakses tanggal 07 november 2016.

Anonim ${ }^{4}$ http://mkpraktis.blogspot.com, pengenalan-arduino.html diakses tanggal 7 juni 2018

Anonim ${ }^{5}$ http://Hypertextnology.Wordpress.Com Sensor Jarak diakses tanggal 12 juni 2018.

Anonim ${ }^{6}$.

http://pemogramanbascom.blogspot.com/20 10/06/pemrograman-lcd-dengan-

mikrokontroller.html diakses tanggal 12 juni 2018.

Anonim ${ }^{7 .} \quad$ http://elektronika dasar.web.id/komponen/lcd-liquid-cristaldisplay-dot-matrix-2×16-m1632 diakses tanggal 12 juni 2018.

Anonim ${ }^{8}$. http://trikueni-desainsistem.blogspot.co.id/2014/03/PengertianMotor-Servo.html diakses tanggal 12 juni 2018.

Anonim 9 . http://trikueni-desainsistem.blogspot.co.id/2014/03/PengertianMotor-Servo.html diakses tanggal 12 juni 2018

Anonim 9 . $\quad h t t p: / / r-d y-$ techno.blogspot.co.id/2013/06/pengertiandan-prinsip-kerja-buzzer.html diakses tanggal tanggal 12 juni 2018. 